\title{
A pelagic ecosystem model simulating production and sedimentation of biogenic particles: role of salps and copepods
}

\author{
Valérie Andersen, Paul Nival \\ Station Zoologique, CEROV, BP 28, F-06230 Villefranche-sur-Mer, France
}

\begin{abstract}
Production and sedimentation of biogenic particles are investigated by a depth-dependent model of a Mediterranean coastal pelagic ecosystem during spring. The model considers living and dead phytoplankton (chiefly diatoms) and its sedimentation, 2 herbivores, salps and copepods, and sedimentation of their fecal pellets and carcases; a sediment trap is assumed to be set up at $200 \mathrm{~m}$ depth. Results underline the major role played by fecal pellets and by both living and dead salps in vertical matter flux. Fecal pellets of salps and copepods constitute $65 \%$ of the material in the trap after a $40 \mathrm{~d}$ simulation period. Although salp and copepod biomasses are similar, the magnitude and composition of the particle flux are much more influenced by salps than by copepods: salp fecal pellets and carcases account for $72 \%$ of the maximum overall flux. The fluxes calculated by this model are in good agreement with those generally recorded in the field: at $200 \mathrm{~m}$ depth, up to $72.3 \mathrm{mgC} \mathrm{m}^{-2} \mathrm{~d}^{-1}$ and a mean of $44.7 \mathrm{mgC} \mathrm{m}^{-2} \mathrm{~d}^{-1}$ over $40 \mathrm{~d}$.
\end{abstract}

\section{INTRODUCTION}

During the last $15 \mathrm{yr}$, studies of the fate of large biogenic particles produced in the marine pelagic environment have revealed that large fast-sinking particles are responsible for the majority of the downward vertical mass flux in the sea. The downward flux of such particles (1) provides almost all the energetic needs of deep-sea fauna (e.g. Wiebe et al. 1979) and (2) controls the distribution and cycling of chemical elements (including radionuclides) in the water column by rapidly transporting these elements to great depths (e.g. Coale \& Bruland 1985). In the open sea, most large particles are biogenic (fecal pellets, carcases, crustacean molts, etc.) and their flux is therefore closely related to the characteristics and variations of the marine pelagic ecosystem.

Given the numerous origins of particles, modelling of the marine ecosystem is essential to appreciate the importance of each particle type in the global flux. Previous ecosystem models are based chiefly on trophic relations between phytoplankton and herbivorous zooplankton. Few models consider sedimentation, and, when they do, either only the sinking of phytoplankton is represented (e.g. Steele \& Henderson 1976, Smith et al. 1983) or fecal pellet sedimentation is briefly described (e.g. the zero-dimensional model of Moloney et al. 1086). To our knowledige, the oniy model including biological processes which describes the production of fecal pellets and the resulting flux is the analytical model of Hofmann et al. (1981), but this is restricted to a population of various sizes of copepods.

Therefore, our purpose is to present a pelagic ecosystem model that considers not only phytoplankton and its sedimentation, but also copepods, salps, and the faeces and carcases derived from them. Salps and copepods are the 2 groups of abundant herbivores in the simulated ecosystem. This depth-dependent 1 dimensional model simulates the general characteristics of the 0 to $200 \mathrm{~m}$ layer pelagic ecosystem in the coastal waters of Villefranche-sur-Mer (Mediterranean Sea). Irradiance, temperature and eddy diffusivity drive this system. We assume that there is no nutrient input in this water column. Simulated vertical distributions of the different phyto- and zooplanktonic organisms and of the fecal pellets are presented. This model allows us to estimate the contribution of each particle type to the vertical biogenic matter flux and its qualitative and quantitative temporal variation, by assuming the deployment of a sediment trap at $200 \mathrm{~m}$ depth.

Salps play a very conspicuous role in our model. They are often present in dense swarms in the ecosys- 
tem we are simulating. Their high filtration and defecation rates (Madin 1982, Andersen 1985), and the particularly high sinking rate of their fecal pellets (Bruland \& Silver 1981, Madin 1982) confer them an essential role in supplying food to the deep-sea organisms (Wiebe et al. 1979, Iseki 1981, Matsueda et al. 1986). Salps also greatly influence cycling of chemical elements and radionuclides in the water column (Coale \& Bruland 1985, Krishnaswami et al. 1985). They ingest organic and inorganic particles, even those of very small size (Harbison \& McAlister 1979) and package them in fecal pellets that are rapidly transported to depth. It is also known that salp fecal pellets are enriched in many trace elements and radionuclides (Krishnaswami et al. 1985), and Coale \& Bruland (1985) reported that the short residence time of particulate thorium observed at some periods on the California coast is governed by the abundance of salps.

\section{MODEL DESCRIPTION}

The model has been developed for spring ( $40 \mathrm{~d}$; from 1 March to 9 April) during which maximum concentrations of phytoplankton and herbivores (copepods, salps) occur. Homogenous layers of $4 \mathrm{~m}$ thick are considered, down to $200 \mathrm{~m}$, the chosen depth to set up a sediment trap.
The following state variables are taken into account (Fig. 1): (1) phytoplankton, (2) living copepods, (3) living salps, (4) dead phytoplankton, (5) fecal pellets of copepods, (6) carcases of copepods, (7) fecal pellets of salps and (8) carcases of salps. Two forcing variables drive the food-web: irradiance and temperature. The physical processes considered are the vertical eddy diffusivity and the sinking of the 5 types of non-living particles and of the living phytoplankton, each of these types being characterized by a different sinking rate. We assume here that phytoplankton consists almost exclusively of diatoms and that ciliates and microflagellates are of minor importance.

\section{Model formulation}

The temporal and spatial variation of each compartment is represented by a 2 -order partial differential equation with 2 independent variables. This equation comprises one time-dependent rate of change of the compartment concentration in a given volume (biological process), one space-dependent rate of change due to eddy diffusivity (second-order physical process) and, for some compartments, one spatial rate of change due to sinking (first-order physical process).

Mathematical formulations representing the different biological processes (e.g. assimilation of dissolved

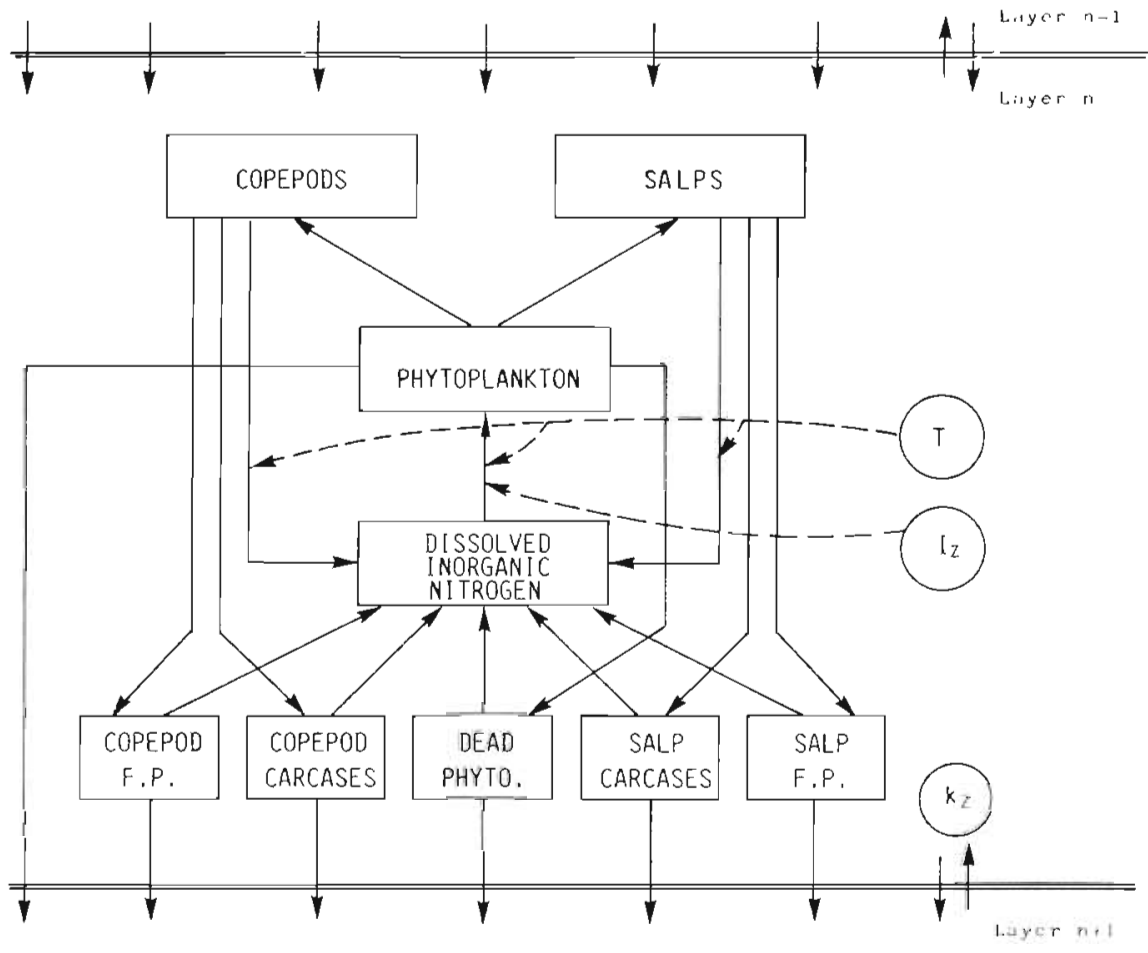

Fig. 1. Block-diagram of the model F.P.: fecal pellets; $I z$ : irradiance; $T$. temperature; $k_{2}$ : vertical eddy diffusivity 
inorganic nitrogen by phytoplankton, mortality and feeding of zooplankton) are those usually used in similar ecosystem models. Their appropriateness and their underlying assumptions are discussed in Andersen et al. (1987) and Andersen \& Nival (1988). The regeneration rate of the different particles is assumed to be constant in the water column. We assume that no decomposition takes place once particles entered the trap, as if the trap is filled with a fixing solution. The model parameters, the mathematical formulations of the biological processes and the differential equation system are listed in Tables 1,2 and 3 respectively.
Our model is not intended to simulate the diel cycles of variables and therefore does not take into account zooplankton vertical migration and diel changes in irradiance. The time-courses of temperature and irradiance are taken from Andersen \& Nival (1988) in which adjustement of the curves to field measurements were worked out. For each $24 \mathrm{~h}$ period and each $4 \mathrm{~m}$ layer the mean irradiance at depth $z, I_{z}\left(1 \mathrm{y} \mathrm{d}^{-1}\right)$, is calculated as follows:

$$
I_{z}=\frac{1}{z_{2}-z_{1}} I_{0} \int_{z_{1}}^{z_{2}} e^{-\alpha z} \mathrm{~d} z
$$

Table 1 Variables and parameters used in the model. Subscripts $p, c$ and $s$ mean respectively phytoplankton, copepods and salps. Subscripts 1, 2, 3, 4 and 5 mean respectively dead phytoplankton, dead copepods, dead salps, copepod fecal pellets and salp fecal pellets

\begin{tabular}{|c|c|c|}
\hline Parameter & Definition & Unit \\
\hline \multicolumn{3}{|l|}{ Variables } \\
\hline$N$ & Dissolved inorganic nitrogen & $\mu \mathrm{g}$-at $\mathrm{N}^{-1}$ \\
\hline$p$ & Phytoplankton & $\mu \mathrm{g}-\mathrm{at} \mathrm{Nl}^{-1}$ \\
\hline C & Copepods & $\mu \mathrm{g}-\mathrm{at} \mathrm{N}^{-1}$ \\
\hline$S$ & Salps & $\mu g-a t N 1^{-1}$ \\
\hline$M_{1}, M_{2}, M_{3}$ & Dead organisms & $\mu g$-at $N 1$ \\
\hline$M_{4}, M_{5}$ & Fecal pellets & $\mu g$-at $\mathrm{Nl}^{-1}$ \\
\hline$I_{z}$ & Irradiance at depth $z$ & ly $d^{-1}$ \\
\hline$T$ & Temperature & ${ }^{\circ} \mathrm{C}$ \\
\hline \multicolumn{3}{|c|}{ Phytoplankton parameters } \\
\hline$\mu_{m}$ & Maximum growth rate & $d^{-1}$ \\
\hline$k_{\mathrm{N}}$ & $\begin{array}{l}\text { Half-saturation constant for dissolved in- } \\
\text { nrganic nitrogen }\end{array}$ & $\mu g$-at $\mathrm{Nl}^{-1}$ \\
\hline$I_{S}$ & Optimal irradiance & $\operatorname{ly~d} d^{-1}$ \\
\hline$\beta_{l}$ & Shape factor for the photoinhibition curve & - \\
\hline$T_{s}$ & Optimal temperature & ${ }^{\circ} \mathrm{C}$ \\
\hline$T_{e}$ & Lower lethal temperature & ${ }^{\circ} \mathrm{C}$ \\
\hline$\beta_{T}$ & $\begin{array}{l}\text { Shape factor for the thermoinhibition } \\
\text { curve }\end{array}$ & - \\
\hline \multicolumn{3}{|c|}{ Zooplankton parameters } \\
\hline$a_{C}, a_{5}$ & Assimilation coefficients & - \\
\hline$i_{m}$ & Maximum ingestion rate for copepods & $d^{-1}$ \\
\hline $\begin{array}{l}{ }^{2} m \\
k\end{array}$ & Ivlev's coefficient for copepods & $l(\mu \mathrm{g}-\mathrm{at} N)^{-1}$ \\
\hline$P_{o}$ & $\begin{array}{l}\text { Threshold concentration for feeding of } \\
\text { copepods }\end{array}$ & $\mu \mathrm{g}$-at $\mathrm{N} \mathrm{l}^{-1}$ \\
\hline$f$ & Filtration rate of salps & $1(\mu \mathrm{g}-\mathrm{at} N)^{-1} \mathrm{~d}^{-1}$ \\
\hline$b_{c}, b_{s}$ & Excretion rate at $0^{\circ} \mathrm{C}$ & $d^{-1}$ \\
\hline$\delta_{c}, \delta_{s}$ & Shape factor for the excretion curve & - \\
\hline \multicolumn{3}{|c|}{ Mortality and regeneration parameters } \\
\hline$m_{m p}, m_{m c}, m_{m s}$ & Maximum mortality rates & $d^{-1}$ \\
\hline$m_{o p}, m_{O C}, m_{O S}$ & Minimum mortality rates & $d^{-1}$ \\
\hline$N_{p}, P_{c}, P_{s}$ & Thresholds of the mortality curve & $\mu g$-at $\mathrm{N} \mathrm{I}^{-1}$ \\
\hline$\Phi_{p}, \Phi_{c}, \Phi_{s}$ & Shape factors for the mortality curve & $\mu g$-at $\mathrm{N} \mathrm{l}^{-1} \mathrm{~d}^{-1}$ \\
\hline$r_{1}, r_{2}, r_{3}, I_{4}, r_{5}$ & Regeneration rates & $\mathrm{d}^{-1}$ \\
\hline \multicolumn{3}{|c|}{ Vertical parameters } \\
\hline$k_{z}$ & Vertical eddy diffusivity at depth $z$ & $m^{2} d^{-1}$ \\
\hline$w_{p}$ & Living phytoplankton sinking rate & $m \mathrm{~d}^{-1}$ \\
\hline$w_{1}, w_{2}, w_{3}$ & Dead organism sinking rates & $m d^{-1}$ \\
\hline$w_{4}, w_{5}$ & Fecal pellet sinking rates & $m d^{-1}$ \\
\hline$a$ & Vertical attenuation exponent & $\mathrm{m}^{-1}$ \\
\hline
\end{tabular}


Table 2. Biological processes used in the model

\begin{tabular}{|c|c|}
\hline Process & Model \\
\hline \multicolumn{2}{|l|}{ Phytoplankton growth } \\
\hline$\mu \quad$ Growth rate of phytoplankton & $\mu=\mu_{m} l_{N} I_{I} l_{T}$ \\
\hline$l_{N} \quad$ Limitation of growth by dissolved inorganic nitrogen & $I_{N}=\frac{N}{k_{N}+N}$ \\
\hline \multirow{2}{*}{$l_{l} \quad$ Limitation by irradiance } & where $x_{I}=I_{z} / I_{s}$ \\
\hline & $x_{I}^{2}+2 \beta_{l} x_{I}+1$ \\
\hline \multirow{2}{*}{$I_{T} \quad$ Limitation by temperature } & $I_{r}=2\left(1+\beta_{T}\right) \frac{x_{T}}{}$ where $x_{T}=\underline{T-T_{e}}$ \\
\hline & $x_{T}^{2}+2 \beta_{T} x_{T}+1 \quad T_{s}-T_{e}$ \\
\hline \multicolumn{2}{|l|}{ Zooplankton consumption } \\
\hline$i_{c} \quad$ Ingestion rate of copepods & $i_{c}=i_{m}\left(1-\mathrm{e}^{-k\left(P-P_{d}\right)}\right.$ \\
\hline$i_{s} \quad$ Ingestion rate of salps & $i_{s}=f P$ \\
\hline \multicolumn{2}{|l|}{ Zooplankton excretion } \\
\hline$e_{c} e_{s} \quad$ Excretion rate of copepods and salps & $e_{c}=b_{c} \delta_{c}^{\top}$ \\
\hline \multicolumn{2}{|l|}{ Phyto- and zooplankton mortality } \\
\hline$m_{p}, m_{c l} m_{s} \quad$ Mortality rate of phytoplankton, copepods and salps & $\begin{array}{l}\text { if } N \leq N_{p} \text { then } m_{p}=m m_{m p} \\
\text { if } N>N_{p} \text { then } m_{p}=\Phi_{p} / N+m_{o p}\end{array}$ \\
\hline
\end{tabular}

Table 3. System of differential equations

$$
\begin{aligned}
& \frac{\partial P}{\partial t}=\left(\mu-m_{p}\right) P-i_{c} C-i_{s} S-w_{p} \frac{\partial p}{\partial z}+k_{z} \frac{\partial^{2} p}{\partial z^{2}} \\
& \frac{\partial C}{\partial t}=\left(a_{c} i_{c}-m_{c}-e_{c}\right) C+k_{z} \frac{\partial^{2} C}{\partial z^{2}} \\
& \frac{\partial S}{\partial t}=\left(a_{s} i_{s}-m_{s}-e_{s}\right) S+k_{z} \frac{\partial^{2} S}{\partial z^{2}} \\
& \frac{\partial N}{\partial t}=r_{1} M_{1}+r_{2} M_{2}+r_{3} M_{3}+r_{4} M_{4}+r_{5} M_{5}+e_{c} C+e_{s} S-\mu P+k_{z} \frac{\partial^{2} N}{\partial z^{2}} \\
& \frac{\partial M_{1}}{\partial t}=m_{p} P-r_{1} M_{1}-w_{1} \frac{\partial M_{1}}{\partial z}+k_{z} \frac{\partial^{2} M_{1}}{\partial z^{2}} \\
& \frac{\partial M_{2}}{\partial t}=m_{c} C-r_{2} M_{2}-w_{2} \frac{\partial M_{2}}{\partial z}+k_{z} \frac{\partial^{2} M_{2}}{\partial z^{2}} \\
& \frac{\partial M_{3}}{\partial t}=m_{s} S-r_{3} M_{3}-w_{3} \frac{\partial M_{3}}{\partial z}+k_{z} \frac{\partial^{2} M_{3}}{\partial z^{2}} \\
& \frac{\partial M_{4}}{\partial t}=\left(1-a_{c}\right) i_{c} C-r_{4} M_{4}-w_{4} \frac{\partial M_{4}}{\partial z}+k_{z} \frac{\partial^{2} M_{4}}{\partial z^{2}} \\
& \frac{\partial M_{5}}{\partial t}=\left(1-a_{5}\right) i_{s} S-r_{5} M_{5}-w_{s} \frac{\partial M_{5}}{\partial z}+k_{z} \frac{\partial^{2} M_{5}}{\partial z^{2}}
\end{aligned}
$$

where $z_{1}$ and $z_{2}=$ respectively the upper and the lower limits of the layer; $I_{0}=$ incident irradiance; $\alpha=$ vertical attenuation exponent, for which a value of $0.066 \mathrm{~m}^{-1}$ was adopted (Béthoux 1968).

Sinking rates of the particles are assumed to be independent of depth. According to the measurements of $\sigma_{t}$ of Braconnot et al. (1966), the eddy diffusivity coefficient is considered increasing with depth but independent of time during the period covered. From these data, the eddy diffusivity coefficient, $k_{z}\left(\mathrm{~m}^{2} \mathrm{~d}^{-1}\right)$ was calculated using the empirical formulation given by Coste (1971): 


$$
k_{z}=\frac{0.096}{\mathrm{~d} \sigma_{t} / \mathrm{d} z}
$$

where $\mathrm{d} \sigma_{t} / \mathrm{d} z=$ density gradient $\left(\mathrm{m}^{-1}\right)$. The values of $k_{z}$ used in the model are given in Table 4.

Table 4. Numerical values for model variables and parameters

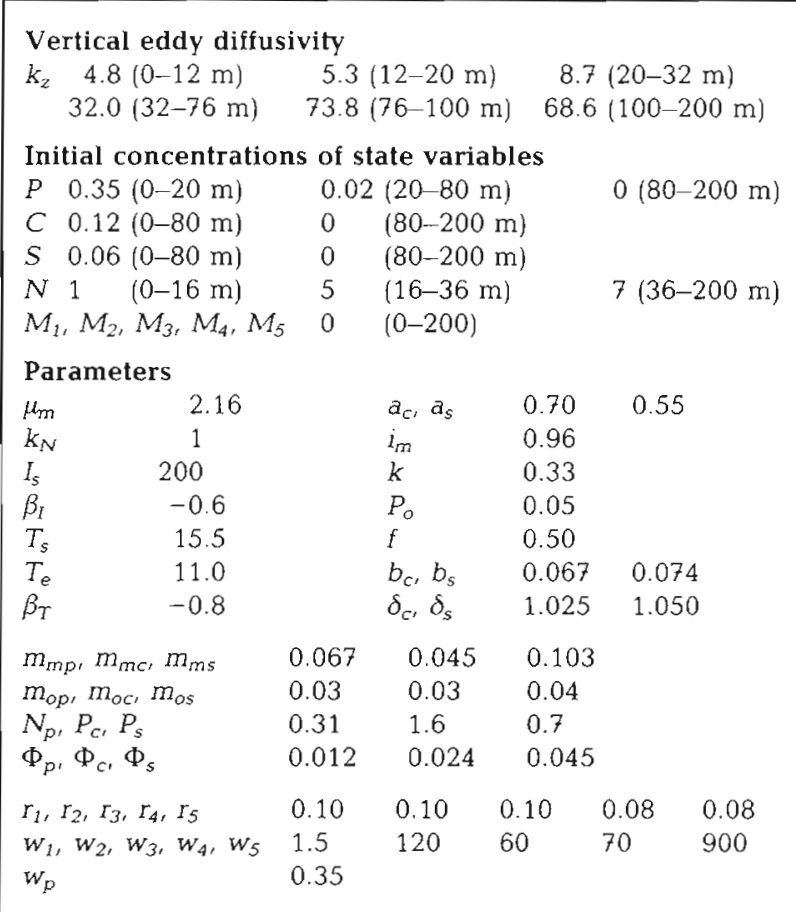

\section{Numerical integration and boundary conditions}

The time rate of change of concentrations in a given volume is calculated by the Runge-Kutta fourth-order method with a constant time step. Depth-dependent rates are calculated by the finite difference method, largely described by Steele \& Henderson (1976) for their model. The stability conditions for this scheme, $\mathrm{d} t$ $\leq \mathrm{d} z / w$ and $\mathrm{d} t \leq \mathrm{d} z^{2} / 4 k_{z}$, where $\mathrm{d} t=$ the time step, $\mathrm{d} z=$ space step, $w=$ the maximum sinking rate and $k_{z}=$ the maximum eddy diffusivity coefficient, are conserved, given the values of the model parameters, with $\mathrm{d} z=$ $4 \mathrm{~m}$ and $\mathrm{d} t=2.5 \mathrm{~min}$.

The equations used here require 2 types of boundary conditions. First the vertical distribution of the state variables is given at an initial time, $t=0$ (cf. Table 4). Boundary conditions at the surface and at the bottom must also be defined. There is no sinking or mixing across the upper boundary; at the bottom there is no mixing but material sinks into and accumulates in the sediment trap.

\section{Estimation of model parameters}

This model aims to reproduce the general characteristics of spring changes in major planktonic groups in the coastal waters of Villefranche. As reference data we used the mean values of organism concentrations found in this area. Copepods generally reach their maximum biomass between mid-March and the beginning of May, with values of 0.15 to $0.75 \mu \mathrm{g}$-at $\mathrm{N} \mathrm{l}^{-1}$ in the 0 to $75 \mathrm{~m}$ layer (years 1967 to 1971; Dallot pers. comm.). Measurements of salp biomass by trawling a net between 3 and $10 \mathrm{~m}$ depth in 1960 and 1963 to 1966 (Braconnot 1971) show that maximum salp abundance occurs between end of March and end of May with a biomass of 0.024 to $0.054 \mu \mathrm{g}$-at $\mathrm{N}^{-1}$. In the case of phytoplankton, Nival (1976) found in 1969 a concentration of $0.52 \mu \mathrm{g}$-at $\mathrm{N} \mathrm{I}^{-1}$ in the 0 to $75 \mathrm{~m}$ layer and during cruise 'Mediprod I' the concentration varied between 0.13 and $1.32 \mu \mathrm{g}$-at $\mathrm{N}^{-1}$ in the 0 to $75 \mathrm{~m}$ layer (Jacques et al. 1973). Collection of these data and estimation of the conversion factors used to convert plankton concentrations into a single unit of nitrogen have been already discussed elsewhere (Andersen \& Nival 1988). In the case of nutrients, nitrate measurements taken during the same period in the northwestern Mediterranean sea (Coste et al. 1972) were used as reference data.

The coefficient values used in the model's biological processes are in the ranges found in the literature, and are those which provide a satisfactory simulation of the mean organism concentration in this area at this period (Table 4). Since our principal concern is to estimate the flux of matter generated by this system, we shall discuss only the values of coefficients related to production and flux of biogenic particles. First, we point out the difference between copepods and salps in the assimilation rate of the food ingested. Copepods assimilate food with a mean efficiency of $70 \%$ (Conover 1966, Corner et al. 1967, Pagano 1980), a value higher than the $55 \%$ efficiency of salps (Andersen 1986).

Salp fecal pellets appear as rectangular flakes, sometimes attached end to end, while copepod fecal pellets are relatively cylindrical. Copepod fecal pellets are also relatively small, with volumes $10^{3}$ to $10^{4}$ less than those of salp fecal pellets. From literature measurements (Table 5), we assumed sinking speeds of $900 \mathrm{~m} \mathrm{~d}^{-1}$ and $70 \mathrm{~m} \mathrm{~d}^{-}$for salp and copepod faeces respectively. Sinking rates of zooplankton carcases have been little studied. As euphausiid carcases settle faster than fecal pellets produced by these crustaceans (Small \& Fowler 1973), we chose a sinking speed of $120 \mathrm{~m} \mathrm{~d}^{-1}$ for copepod carcases. Concerning salp carcases, we assumed that this gelatinous material sinks at lower rate than copepod carcases, and at a rate similar to that 
Table 5. Sinking rates of different particle types. Average sinking rates are in brackets or designed by an asterisk

\begin{tabular}{|c|c|c|}
\hline Particle types & Sinking rate $\left(\mathrm{m} \mathrm{d}^{-1}\right)$ & Source \\
\hline \multicolumn{3}{|l|}{ Salp fecal pellets } \\
\hline 2 different species & $\begin{array}{l}450-1210(836) \\
600-2700(1680)\end{array}$ & Bruland \& Silver 1981 \\
\hline 3 different species & $320-1987(1060)$ & Madin 1982 \\
\hline \multicolumn{3}{|l|}{ Copepod fecal pellets } \\
\hline Acartia tonsa & $80-150$ & Honjo \& Roman 1978 \\
\hline Calanus finmarchicus & $180-220$ & \\
\hline \multicolumn{3}{|l|}{ Different species } \\
\hline various ages & $10-145$ & Paffenhöfer \& Knowles 1979 \\
\hline adults & $54-145$ & \\
\hline \multicolumn{3}{|l|}{ Different species } \\
\hline $\begin{array}{l}\text { various ages } \\
\text { adults }\end{array}$ & $\begin{array}{c}19.5-100.7 \\
12-225\end{array}$ & Small et al. 1979 \\
\hline \multicolumn{3}{|l|}{ Calanus sp. } \\
\hline on diatom diet & $70-171(123.3)$ & Bienfang 1980a \\
\hline on flagellate diet & $51-152(87.9)$ & \\
\hline \multicolumn{3}{|l|}{ Larvacean houses } \\
\hline Oikopleura dioica & $64.9^{\circ}$ at $5^{\circ} \mathrm{C}$ & Silver \& Alldredge 1981 \\
\hline & $57.0^{\circ}$ at $16^{\circ} \mathrm{C}$ & \\
\hline Oikopleura dioica & $26-157\left(4-25^{\circ} \mathrm{C}\right)$ & Gorsky et al. 1984 \\
\hline \multicolumn{3}{|l|}{ Diatom cells } \\
\hline Different species & $0.10-2.10^{\circ}$ & Smayda \& Boleyn 1965, 1966a, b \\
\hline \multicolumn{3}{|l|}{ Freshwater diatoms } \\
\hline exponential phase & $0.08-0.67^{\circ}$ & Titman \& Kilham 1976 \\
\hline stationary phase & $0.24-1.87^{\circ}$ & \\
\hline Fragilaria crotonensis & $0.27^{\circ}$ & Burns \& Rosa 1980 \\
\hline \multicolumn{3}{|l|}{ Natural community } \\
\hline $3-20 \mu \mathrm{m}$ & $0.34-0.83^{\circ}$ & Bienfang 1980b \\
\hline $20-102 \mu \mathrm{m}$ & $0.95-1.65^{\circ}$ & \\
\hline Natural community & $0.32-1.69(0.64)$ & Bienfang 1981 \\
\hline Natural community & $0.21^{\circ}$ & Smayda \& Bienfang 1983 \\
\hline
\end{tabular}

of larvacean houses (cf. Table 5). Sinking rates of diatoms are very low compared with those of faeces and carcases (cf. Table 5). Increasing sedimentation rate with nutrient impoverishment of the milieu has been suggested by some authors (Titman \& Kilham 1976, Harrison \& Turpin 1982) but, as this phenomenon does not seem a general rule (Bienfang 1981), the sinking rate in the model was taken as constant.

Some laboratory studies have shown that at high temperatures, between 20 and $25^{\circ} \mathrm{C}$, fecal pellets are degraded in periods of several hours to several days (Honjo \& Roman 1978, Paffenhöfer \& Knowles 1979. Turner 1979). Pomeroy \& Deibel (1980) suggest that residence time of doliolid pellets in the water column might be only $5 \mathrm{~d}$, based on decomposition rates at 15 to $20^{\circ} \mathrm{C}$, although at $5^{\circ} \mathrm{C}$ degradation is always weak and slow (Honjo \& Roman 1978, Turner 1979). Decomposition of fecal pellets of a gastropod would require $78 \mathrm{~d}$ at $19^{\circ} \mathrm{C}$ (Peduzzi \& Herndl 1986), copepod fecal pellets at $18^{\circ} \mathrm{C}$ would require $50 \mathrm{~d}$ (Jacobsen \& Azam
1984). Sediment trap studies suggest that decomposition of large particles, due to bacteria and protozoa, is slow in the water column (Ducklow et al. 1985). Given the absence of consistent values in the literature, we chose therefore decomposition rates of 0.08 to $0.10 \mathrm{~d}^{-1}$, similar to those used in other ecosystem models $10.5 \mathrm{~d}^{-1}$ in O'Brien \& Wroblewski 1973,0.1 $\mathrm{d}^{-1}$ in Vinogradov et al. 1973). Carcases are degraded faster than the fecal pellets produced by the same organisms: over $60 \mathrm{~h}$, the sinking speed of euphausiid carcases decreases from 4000 to $2400 \mathrm{~m} \mathrm{~d}^{-1}$, reflecting an important and rapid decomposition, while the sinking speed of the fecal pellets remains constant (Small \& Fowler 1973). Harding (1973) reported that killed copepods decomposed within $11 \mathrm{~d}$ at $4{ }^{\circ} \mathrm{C}$ and within $3 \mathrm{~d}$ at $22^{\circ} \mathrm{C}$, periods which appear shorter than those reported for the decomposition of copepod fecal pellets. Because of these results, a slightly higher regeneration rate for carcases $\left(0.10 \mathrm{~d}^{-1}\right)$ than for fecal pellets $\left(0.08 \mathrm{~d}^{-1}\right)$ has been assumed. 
Fig. 2. Simulated vertical distribution on 3 dates (Days 15, 23 and 40). Above: (-) living phytoplankton; (---) dead phytoplankton; (-.) dissolved inorganic nitrogen. Below: (-) copepods; (- - - ) salps

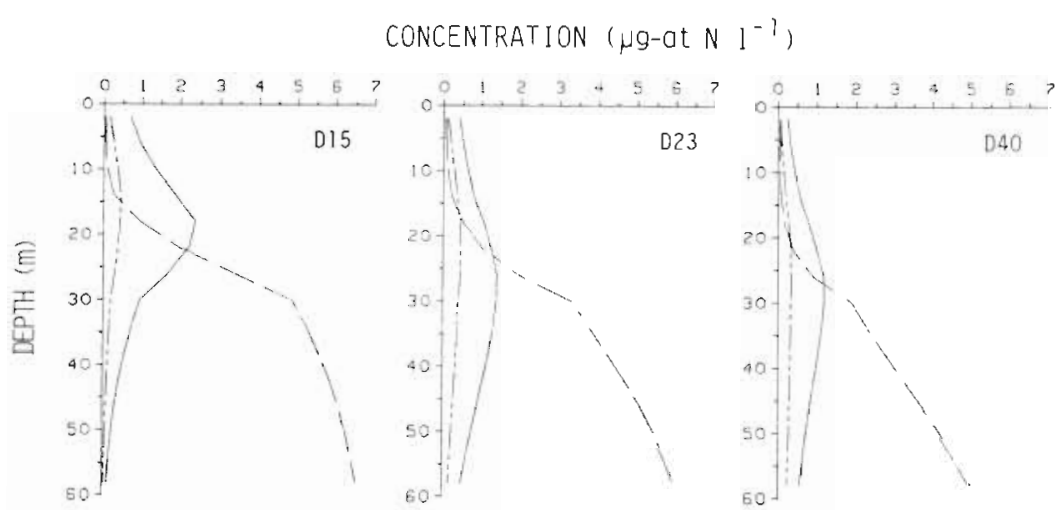

CONCENTRATION ( $\left.\mu g-O T \mathrm{~N}^{-1}\right)$

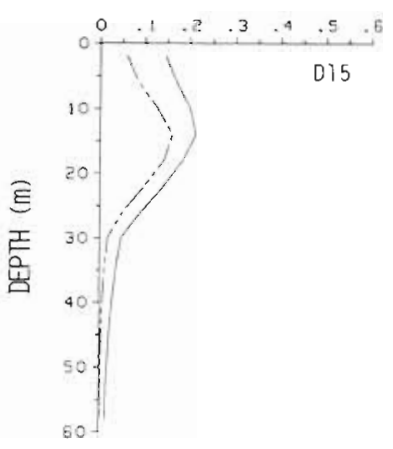

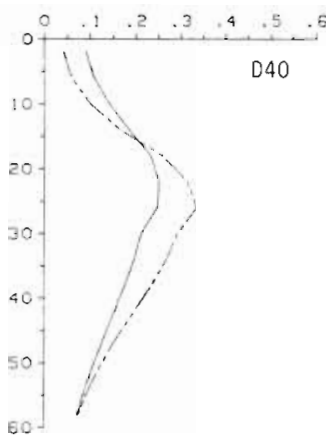

\section{RESULTS}

Fig. 2 shows the simulated vertical distributions in the 0 to $60 \mathrm{~m}$ layer (concentrations being nearly constant below) of live and dead phytoplankton, dissolved inorganic nitrogen, and copepods and salps, for 3 selected dates in the simulation: Day 15, the phytoplankton maximum; Day 23, the herbivore maximum; and Day 40, the end of the simulation. The set of model parameters used and the model structure allow reproduction of the general temporal variation of the variables for the studied area. The phytoplankton bloom is at a maximum on Day 15 (15 March in the model) with a concentration of $2.37 \mu \mathrm{g}$-at $\mathrm{N} \mathrm{I}^{-1}$ in the 16 to $20 \mathrm{~m}$ layer, and a mean concentration of $0.78 \mu \mathrm{g}$-at $\mathrm{l}^{-1}$ in the 0 to $76 \mathrm{~m}$ layer, a value in the range of the reference data given above. The vertical profile of dead phytoplankton nearly follows that of living phytoplankton. Dissolved inorganic nitrogen distribution is typical: exhausted in surface waters, higher in deeper waters, with a clear nitricline; concentrations are similar to those measured offshore Villefranche by Coste et al. (1972). On Day 15 copepod biomass is slightly higher than salp biomass; thereafter, salps become clearly more abundant than copepods. For both kinds of zooplankton, maximum concentrations occur nearly simul- taneously (Day 22 for copepods, Day 23 for salps). Thcreafter, the difference in biomass between salps and copepods diminishes. In the 0 to $200 \mathrm{~m}$ layer salp biomass was $0.061 \mu \mathrm{g}$-at $\mathrm{N}^{-1}$ on Day $23(0.068 \mu \mathrm{g}$-at $\mathrm{N}$ $\mathrm{l}^{-1}$ on Day 27). Maximal concentrations observed in situ varied from 0.024 to $0.054 \mu \mathrm{g}$-at $\mathrm{N} \mathrm{I}^{-1}$. These values have been measured between 3 and $10 \mathrm{~m}$ depth; in our model salp concentrations at these depths are higher, but net tows taken in daytime certainly underestimate salp biomass. In fact, Salpa fusiformis, the predominant salp species in the plankton of Villefranche during spring, appears to undergo vertical migration, being rather at depth during day (Franqueville 1971, Harbison \& Campenot 1979, Bruland \& Silver 1981). Copepod concentration in the 0 to $76 \mathrm{~m}$ layer $(0126 \mu \mathrm{g}$ at $\mathrm{N}^{-1}$ on Day 22, $0.139 \mu \mathrm{g}$-at $\mathrm{N}^{-1}$ on Day 29) appears a little low compared with reference data.

We shall now consider the vertical profiles themselves. During the simulation the phytoplankton maximum occurs between 16 and $20 \mathrm{~m}$. This can be related to 2 factors: first, as phytoplankton growth is limited in the upper layers where nutrients are exhausted, phytoplankton develops at levels where nutrients are still abundant although irradiance is not optimal; and, second, sinking of phytoplankton transports it to deeper layers. The effects of sinking appear clearly on the 

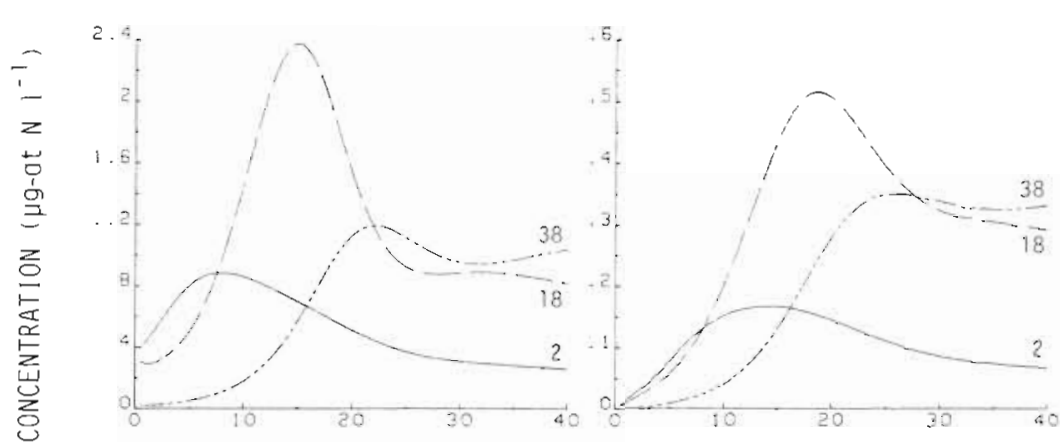

Fig. 3. Simulated temporal variation of living phytoplankton (left) and dead phytoplankton (right) at 3 depths $(2,18$ and $38 \mathrm{~m})$

TIME (d)

curves: on Day 15 the peak occurs in the 16 to $20 \mathrm{~m}$ layer, on Day 23 in the 24 to 28 m layer.

Maximum concentrations of copepods and salps develop where phytoplankton is most abundant: in the 16 to $20 \mathrm{~m}$ layer for copepods, in the 20 to $24 \mathrm{~m}$ layer for salps. Below $50 \mathrm{~m}$ herbivores are nearly absent, as a result of 2 assumptions made in the model: first copepods and salps are considered as strict herbivores and ingest neither dead phytoplankton nor faeces, and, second, the vertical migration which these organisms can undergo is not taken into account.

Effects of sinking of living and dead phytoplankton are clearly illustrated by comparing the temporal variation of these variables at different depths (Fig. 3). As depth increases, the temporal maximum is delayed for all variables under consideration: at depths 2, 18 and $38 \mathrm{~m}$, the peak appears, for living phytoplankton, on Days 8,15 and 22 respectively; for dead phytoplankton, on Days 14, 19 and 26 respectively.

The simulated vertical profiles of copepod and salp fecal pellets in the 0 to $200 \mathrm{~m}$ water column are presented in Fig. 4. As a consequence of high sinking rates of fecal pellets, these profiles are very different from

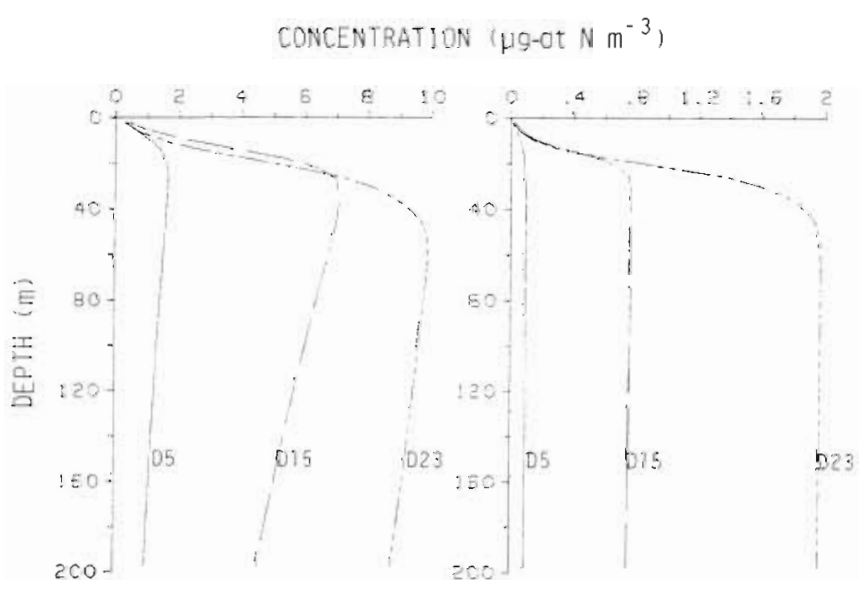

Fig. 4. Simulated vertical distribution of fecal pellets of copepods (left) and salps (right) on 3 dates (Days 5, 15 and 23) those of the organisms that produced the pellets: no very pronounced maximum can be observed, with fecal pellets reaching the bottom very rapidly as soon as they are produced. In surface layers, fecal pellets are sparse due to their sinking speed and to low concentrations of copepods and salps. The just-discernible maximum concentration in the water column becomes deeper with time. Below the maximum, concentration of copepod fecal pellets decreases linearly, while it remains constant for salp fecal pellets, showing a very fast enrichment of the deep layers. Moreover, nitrogen concentrations of salp fecal pellets in this water column are about 5 to 10 times lower than those of copepod fecal pellets although copepod and salp concentrations are of the same order of magnitude.

The importance of fecal pellets as a means of transporting energy to deep-sea organisms is clearly brought out by this model. While salps and copepods are nearly absent below $60 \mathrm{~m}$ in the model, fecal pellets are abundant there. Vertical distributions of copepods and salps carcases (sinking rates of 120 and $60 \mathrm{~m} \mathrm{~d}^{-1}$ respectively) look like those of copepod fecal pellets. The temporal peak of copepod fecal pellets is delayed with increasing depth (Fig. 5). At $18 \mathrm{~m}$, where herbivore biomass is maximal, feces concentration is low, as a consequence of the few fecal pellets coming from the upper layers. For salp feces, no marked difference is observed between 58 and $178 \mathrm{~m}$, due to their very high sinking rate.

Composition of the particulate organic matter which accumulated over the $40 \mathrm{~d}$ simulation in the sediment trap assumed to be set up at $200 \mathrm{~m}$ depth is presented in Fig. 6. The relative contribution of nitrogen by each particle type to the total particulate nitrogen in the trap is expressed as a percentage. We mention again that we have assumed that no decomposition took place once particles entered the trap. Phytoplankton cells are not included because they account for only $0.07 \%$ of the total nitrogen mass 10.02 and $0.05 \%$ for living and dead phytoplankton respectively). Salp fecal pellets constitute the major part of the material, although salp 
Fig. 5. Simulated temporal variation of fecal pellets of copepods (left) and salps (right) at 4 depths: (-) $18 \mathrm{~m}$; (- - $58 \mathrm{~m} ;(--)$ $118 \mathrm{~m} ;(-\cdots) 178 \mathrm{~m}$

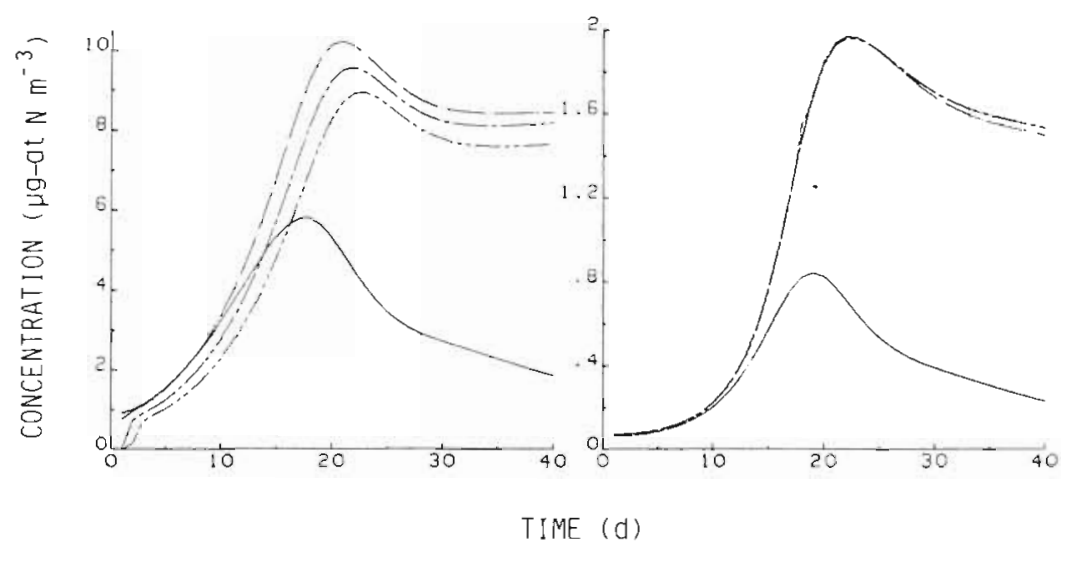

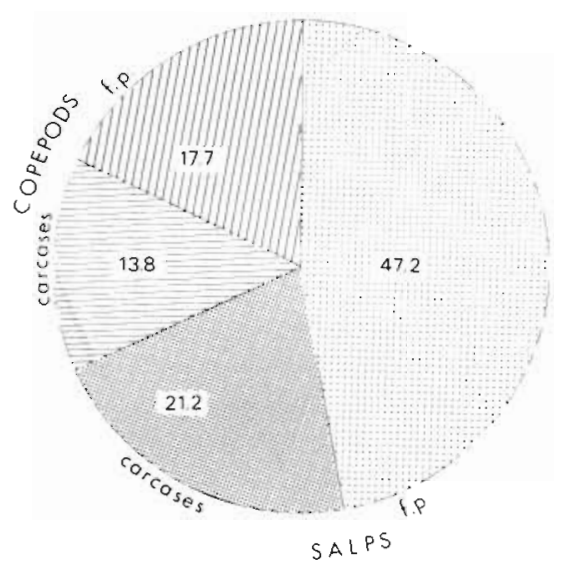

Fig. 6. Composition of particulate organic matter in the $200 \mathrm{~m}$ trap after $40 \mathrm{~d}$ of simulation. For each particle type, percentage of nitrogen mass of total nitrogen in the trap is calculated. f.p.: fecal pellets

and copepod biomasses are similar. This results chiefly from 2 factors: first, a very high sinking rate of salp fecal pellets; and, second, a lower assimilation rate of food ingested in salps than in copepods (cf. Table 4). The percentage of salp carcases is higher than that of copepod carcases although the latter have a higher sinking rate than the former. This apparent contradiction is explained by the slightly higher biomass and death rate of salps in comparison to copepods (cf Table 4). Of the total organic matter in the trap, $68.4 \%$ originates from salps, so salps certainly play a predominant role in the transport of matter to the deepsea. Fecal pellets of both salps and copepods account for the major part of the matter in the trap (64.9\%).

The time-courses of the daily total matter flux and of the daily flux specific to each particle type are presented in Fig. 7. Again the important contribution of fecal pellets appears: the curve of the total flux follows, by shape and magnitude, the curve of the salp fecal pellet flux (Fig. 7a). Maximum flux occurs on Day 28 with a contribution of $72.1 \%$ of salp feces and carcases. Herbivore fecal pellet fluxes reach a maximum on Day 23 , while fluxes via carcases are at a maximum on Days 31 to 33 . Changes with time in the composition of the flux can be clearly seen by this type of model (Fig. 7b) The contribution of fecal pellet to total flux is maximum on Day $19(81.2 \%)$ when phytoplankton is abundant decreasing at the end of the simulation when phytoplankton concentration is lower and herbivore mortality higher.
Fig. 7. Variation of particle fluxes during the $40 \mathrm{~d}$ of simulation. (a) Flux. (b) Cumulative flux - a given flux is represented by the height between 2 adjacent curves. cc: copepod carcases; cfp: copepod fecal pellets; sc: salp carcases; sfp: salp fecal pellets; $t$ total

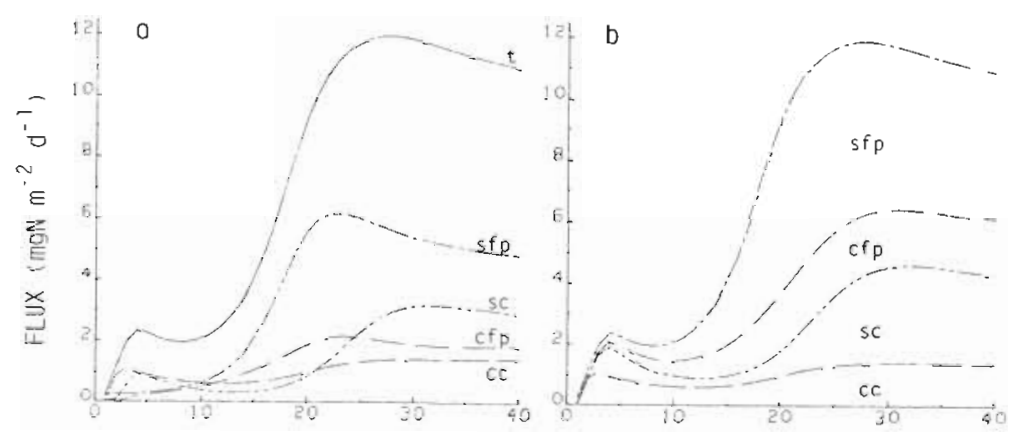

TIME (d) 


\section{DISCUSSION}

We saw in the model that herbivore fecal pellets accounted for $64.9 \%$ of the accumulated matter in the sediment trap after the $40 \mathrm{~d}$ simulation period, and yet at one point in time (Days 18 and 19) they represented up to $81.2 \%$ of the total flux. These results are similar to those observed in the field from sediment traps which showed that fecal pellets of zooplanktonic organisms, and particularly those of salps, contributed highly to the matter flux and often accounted for a large part of the matter in the trap. Iseki (1981) found a predominance of salp fecal pellets in a $200 \mathrm{~m}$ trap, as did Matsueda et al. (1986) in a $740 \mathrm{~m}$ trap; during the cruise 'CEROP I', salp fecal pellets accounted for $90 \%$ of the matter collected in traps at 58 and $580 \mathrm{~m}$ (Coale $\&$ Bruland 1985). Contributions of fecal pellets to the flux, and producing organisms, vary according to the area and to the period. Fowler \& Knauer (1986) report unpublished data of Knauer \& Martin who observed in one of the VERTEX experiments that up to $40 \%$ of the $C$ flux could be accounted for by large pellets produced by the pelagic crab Pleuroncodes planipes. In the northwest Mediterranean Sea, in an area similar to that taken as reference in our model, about $70 \%$ of the total dry weight in a $200 \mathrm{~m}$ trap was due to copepod fecal pellets early in May 1986 (Fowler et al. 1987); it should be noted that 1986 in this region was exceptional due to the lack of a salp bloom in spring. Numerous studies illustrating the importance of fecal pellets in the vertical matter flux are available and we shall mention only 2 more: Small et al. (1983) reported that $41 \%$ of the total C flux into a $120 \mathrm{~m}$ trap could have been via fecal pellets from small and large zooplankton (including salps) and Bishop et al. (1977) showed that fecal material accounted for $99 \%$ of the vertical flux through $388 \mathrm{~m}$.

In our model, at the opposite extreme from fecal pellets and carcases, living phytoplankton accounted for only $0.02 \%$ of the total nitrogen in the trap after a $40 \mathrm{~d}$ simulation. Sinking of intact algae out of this 0 to $200 \mathrm{~m}$ water column therefore appears to be of minor importance. Lorenzen et al. (1983) reached similar conclusions for waters south of the Hawaiian Islands: at 100 and $400 \mathrm{~m}$ the daily flux of chlorophyll represented only 0.8 and $0.08 \%$ of the integrated standing crop of chlorophyll above these depths.

Flux values from the literature and from our model are collected in Table 6 . One must keep in mind some limitations when examining these values: the flux values have been determined in various areas and at different periods, and we used several conversion coefficients to obtain a given unit of flux. According to literature data, we assumed a $\mathrm{C} / \mathrm{N}$ ratio (by atoms) of 7 for salp fecal pellets (Bruland \& Silver 1981, Madin
1982, Small et al. 1983), of 6.5 for copepod fecal pellets (Small et al. 1983), and of 4.5 for copepod and salp carcases (Boucher et al. 1976, Madin et al. 1981, Small et al. 1983, Ikeda \& Bruce 1986). Carbon is taken as $28 \%$ of dry weight in feces (Madin 1982, Small et al. 1983 ) and as $40 \%$ in herbivore carcases (e.g. Small et al. 1983). Flux values given by our model are comparable to those reported in the literature. Fluxes of salp fecal pellets (maximum $43.2 \mathrm{mgC} \mathrm{m}^{-2} \mathrm{~d}^{-1}$, mean $24.5 \mathrm{mgC} \mathrm{m}^{-2} \mathrm{~d}^{-1}$ over the $40 \mathrm{~d}$ simulation) are of the same order of magnitude as those observed by Iseki (1981) and Matsueda et al. (1986) (10.5 and $23 \mathrm{mgC} \mathrm{m}^{-2}$ $\mathrm{d}^{-1}$ respectively). Flux estimates of Wiebe et al. (1979) are not based on sediment trap results but on data on salp biomass in the 0 to $100 \mathrm{~m}$ layer and on defecation and death rates. This calculation allows a relatively complete comparison between the results of Wiebe et al. (1979) and those of the present model. In the 2 cases, salp biomass in the 0 to $100 \mathrm{~m}$ layer is much the same: $0.144 \mu \mathrm{g}$-at $\mathrm{N}^{-1}$ for Salpa aspera in Wiebe et al. and a maximum of $0.136 \mu \mathrm{g}$-at $\mathrm{N}^{-1}$ for Salpa fusiformis in the model. Moreover, values of the fluxes via carcases and fecal pellets are of the same order of magnitude: $3.6 \mathrm{mgC} \mathrm{m}^{-2} \mathrm{~d}^{-1}$ for $S$. aspera carcases (the only published estimate of salp carcase flux to our knowledge), and $14.4 \mathrm{mgC} \mathrm{m}^{-2} \mathrm{~d}^{-1}$ at the maximum for $S$. fusiformis carcases; simulated fecal pellet flux reaches a maximum of $43.2 \mathrm{mgC} \mathrm{m}^{-2} \mathrm{~d}^{-1}$, within the range of the data of Wiebe et al. (8.5 to $137 \mathrm{mgC} \mathrm{m}^{-2} \mathrm{~d}^{-1}$ ). Simulated copepod fecal pellet flux is about 3 times lower than that of salp feces, and is comparable to the lower limit of the value range observed by Fowler et al (1987) in an area similar to that taken as reference in the present study. The model does not simulate the higher flux observed by these authors and this could be related to 2 factors: the simulated copepod concentrations were lower than the in situ ones, and our simulated conditions included competition with salps which was absent during the Fowler et al. study. The fluxes calculated from the copepod population dynamics model of Hofmann et al. (1981) appear comparatively very low. The general agreement of total fecal pellet flux in our simulation with data of Bishop et al. (1977) as well as comparison of the total flux with data of Karl \& Knauer (1984) and Knauer et al. (1984) emphasizes the agreement between fluxes calculated by the model and observed ones in the field.

This simple ecosystem model reflects the conspicuous role of salps in the vertical flux and cycling of matter, a role previously recognized in situ (Coale \& Bruland 1985, Krishnaswami et al. 1985). Although the model generated satisfactory values of particulate flux, it is somewhat simplistic and includes some hypotheses which could perhaps be improved. The food web considered here is very simple and it would be probably 
Table 6. Comparison of flux values cited in the literature and those found in the model

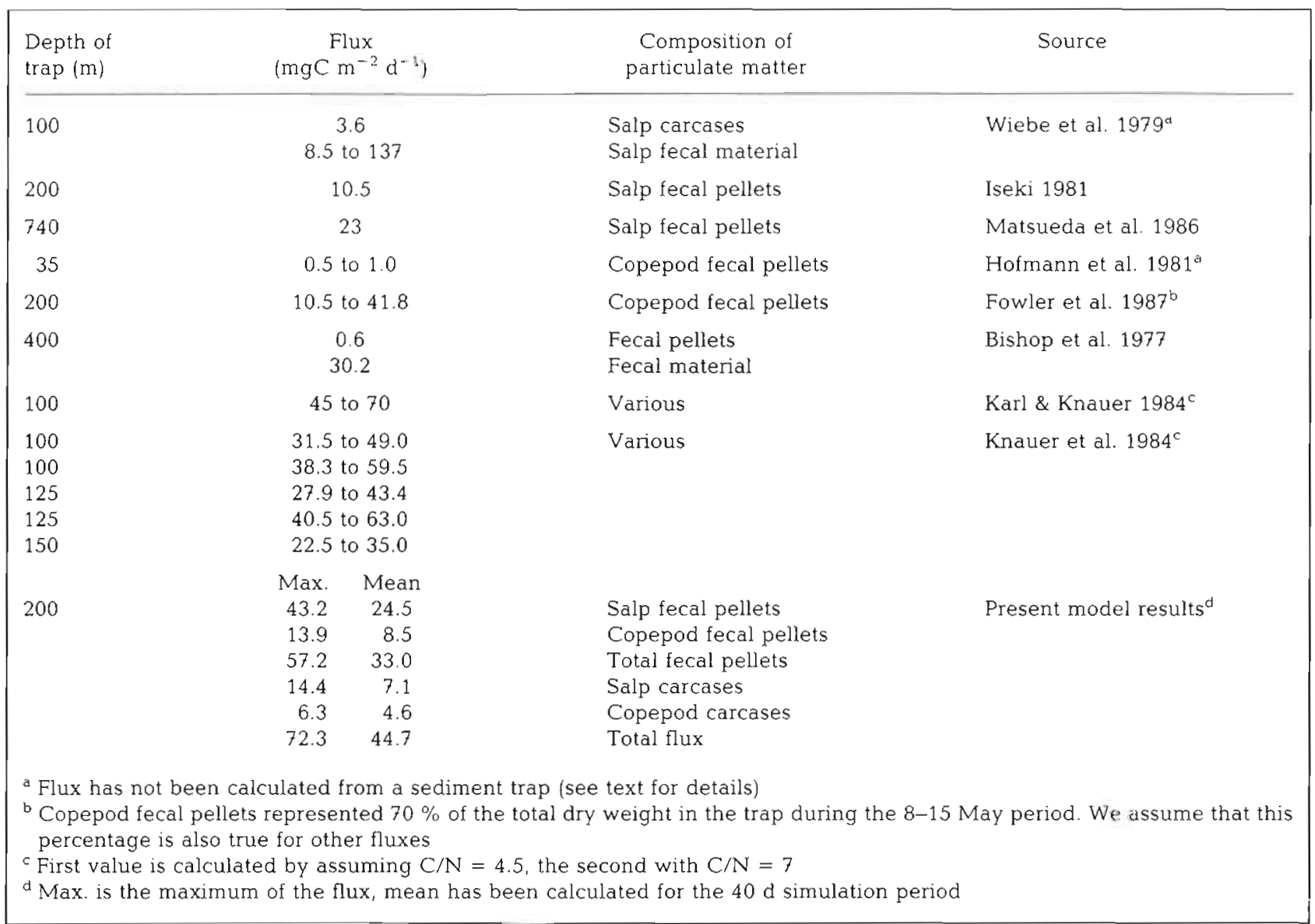

necessary to take into account some other planktonic organism types which can be important (appendicularians for example). Even so, as a first step, some processes represented in the present structure of the model would have to be modified. The main process to consider would be, in our opinion, the ingestion of dead phytoplankton and feces by copepods and salps. Various studies reported that copepods feed not only on living organisms, but also on dead phytoplankton and on fecal pellets produced by the same copepod species, and this at about the same rates as for a live phytoplankton diet (Paffenhöfer \& Strickland 1970, Paffenhöfer \& Knowles 1979). To our knowledge, no such laboratory study has been done for salps, but there is no reason to exclude the possibility of the same phenomenon. In the model, salps and copepods are very sparse below $50 \mathrm{~m}$; ingestion of non-living matter would contribute to reproducing their non-negligible concentrations observed in deeper waters in the field.

In the present work, sinking rate of non-living particles has been taken as independent of time and depth. However, Smayda \& Boleyn $(1965,1966 \mathrm{a}$, b) have observed increasing sinking rate with culture age in several algal species, and Lännergren (1979) noticed higher settling rates in situ during the post-bloom period when cells are senescent. Bienfang (1980b) observed a variation of phytoplankton sinking rate with depth: it was significantly lower at $71 \mathrm{~m}$ than at 24 and $400 \mathrm{~m}$. Various processes can also influence sedimentation of fecal pellets. For example, their degradation during descent or their adherence to gelatinous aggregates, such as salp carcases or appendicularian houses (Silver \& Alldredge 1981), slow their fall. On the other hand, vertical migration of zooplankton can accelerate the downward matter transport by production of fecal pellets at depth during the day. Because numerous copepods and several salp species undergo conspicuous diel vertical migrations, it would therefore be necessary to take this into account in further studies.

Flux of biogenic particles in the water column can be estimated by 3 methods: (1) from sediment traps or pumps, (2) from measurements of the zooplankton composition and abundance, particle production rates and sinking rates, (3) from a model of the pelagic ecosystem. The first method integrates flux over rather long periods and provides only little information on the 

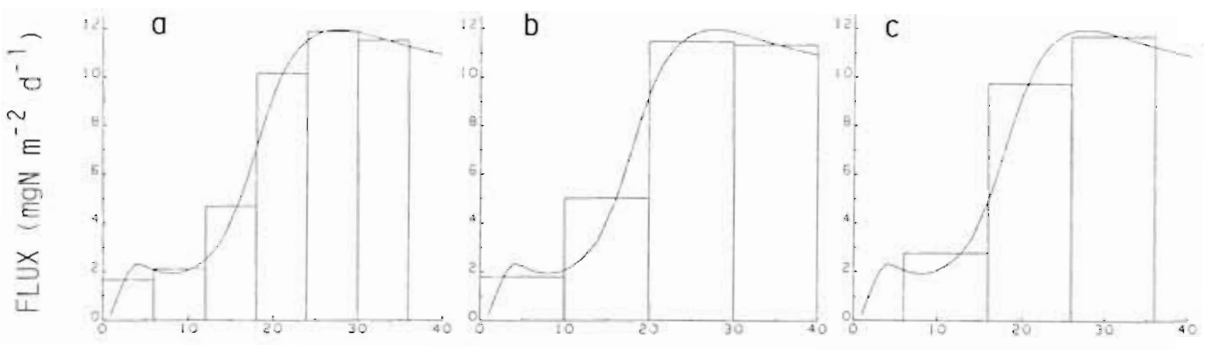

Fig. 8. Comparison of daily flux values with flux values calculated with different time-steps. (a) $\mathrm{d} t=$ $6 \mathrm{~d}_{\text {; }}$ (b) $\mathrm{d} t=10 \mathrm{~d}$; (c) $\mathrm{d} t=10 \mathrm{~d}$, beginning on Day 6
TIME (d)

flux changes as a function of the variation of the composition or abundance of the zooplankton populations. As an illustration we can compare the daily fluxes and the fluxes calculated from the matter in the trap after different time-steps (Fig. 8). When the time-step increases, daily fluxes and integrated fluxes become more different (under- or overestimation of 3.1 and $4.2 \mathrm{mgN} \mathrm{m}^{-2} \mathrm{~d}^{-1}$ at a maximum with time-steps of 6 and $10 \mathrm{~d}$ respectively) and this discrepancy increases again when the trap is assumed to be set up after the fifth day of simulation (maximum difference of $4.8 \mathrm{mgN} \mathrm{m}^{-2} \mathrm{~d}^{-1}$ ). The flux estimates from measurement of the in situ zooplankton biomasses are generally intermittent, due to the technical difficulties in making such measurements at frequent intervals over long periods. An adequate modelling of this flux based on a set of measured biomasses allows one to follow continuously the qualitative and quantitative variation of the flux. We think that these 3 methods are interdependent. The comparison of model results with trap measurements can help elucidate the workings of the trophic web and may permit the testing of hypotheses. Thus, modelling of the marine pelagic ecosystem complements studies in the field.

Acknowledgements. We thank N. Holland and A. Leonard who improved this manuscript by their comments. The present work was supported by the Centre National de la Recherche Scientifique (CNRS)-U.A. 716 (department Terre Océan Atmosphère Espace [TOAE]) as a part of the project DYFAMED (program F.M.O of the Institut National des Sciences de l'Univers [INSU]).

\section{LITERATURE CITED}

Andersen, V (1985). Filtration and ingestion rates of Salpa fusiformis Cuvier (Tunicata: Thaliacea): effects of size, individual weight and algal concentration. J. exp. mar. Biol. Ecol. 87 13-29

Andersen, V (1986). Effect of temperature on the filtration rate and percentage of assimilation of Salpa fusiformis Cuvier (Tunicata: Theliacea). Hydrobiologia 137 135-140

Andersen, V., Nival, P. (1988). Modèle d'écosystème pélagique des eaux cottières de la mer Ligure. Oceanol. Acta (1n press)
Andersen, V., Nival, P., Harris, R. P. (1987). Modelling of a planktonic ecosystem in an enclosed water column. J. mar. biol. Ass. U. K. 67 : 407-430

Béthoux, J. P. (1968). Adaptation d'une thermopile à la mesure de l'éclairement sous-marin. Thèse 3ème cycle, Géophysique, Université Paris VI, France

Bienfang, P. K. (1980a). Herbivore diet affects fecal pellet settling. Can. J. Fish. aquat. Sci. 37: 1352-1357

Bienfang, P. K. (1980b). Phytoplankton sinking rates in oligotrophic waters off Hawaii, U.S.A. Mar. Biol. 61: 69-77

Bienfang, P. K. (1981). Sinking rates of heterogeneous, temperate phytoplankton populations. J. Plankton Res. 3: 235-253

Bishop, J. K. B., Edmond, J. M., Ketten, D. R., Bacon, M. P., Silker, W B. (1977). The chemistry, biology, and vertical flux of particulate matter from the upper $400 \mathrm{~m}$ of the equatorial Atlantic Ocean. Deep Sea Res. 24: 511-548

Boucher, J., Razouls, C., Razouls, S. (1976). Composition chimique élémentaire en carbone et azote de Centropages typicus et Temora stylifera. Analyse des variations en fonction de la physiologie et des conditions écologiques. Cah. Biol. mar. 17: 37-43

Braconnot, J. C. (1971). Contribution à l'étude biologique et écologique des tuniciers pélagiques salpides et doliolides. I Hydrologie et écologie des salpides. Vie Milieu 22: $257-286$

Braconnot, J. C., Carré, C., Goy, J., Laval, P., Sentz-Braconnot, E. (1966). Conditions hydrologiques pendant les années 1963 et 1964 en un point au large de Villefranche-sur-Mer (A. M.). Particularités dues à l'hiver froid de 1963. Cah. Océanogr 18: 423-437

Bruland, K. W., Silver, M. W. (1981). Sinking rates of fecal pellets from gelatinous zooplankton (salps, pteropods, doliolids). Mar. Biol. 63: 295-300

Burns, N. M., Rosa, F. (1980). In situ measurement of the settling velocity of organic carbon particles and 10 species of phytoplankton. Limnol. Oceanogr. 25: 855-864

Coale, K. H., Bruland, K. W. (1985). ${ }^{234}$ Th $\cdot{ }^{238} \mathrm{U}$ disequilibria within the California Current. Limnol. Oceanogr. 30 : 22-33

Conover, R. J. (1966). Assimilation of organic matter by zooplankton. Limnol. Oceanogr. 11. 338-345

Corner, E. D. S., Cowey, C. B., Marshall, S. M. (1967). On the nutrition and metabolism of zooplankton. $V$ Feeding efficiency of Calanus finmarchicus. J. mar biol. Ass. U. K. 47 . $113-120$

Coste, B. (1971). Les sels nutritifs entre la Sicile, la Sardaigne et la Tunisie. Cah. Océanogr 23: 49-83

Coste, B., Gostan, J., Minas, H. J. (1972). Influence des conditions hivernales sur les productions phyto- et zooplanctoniques en Méditerranée Nord-Occidentale. I. Structures 
hydrologiques et distribution des sels nutritifs. Mar. Biol. 16: $320-349$

Ducklow, H. W., Hill, S. M., Gardner, W. D. (1985). Bacterial growth and the composition of particulate organic carbon collected in sediment traps. Cont. Shelf Sci. 4: 445-464

Fowler, S. W., Knauer, G. A. (1986). Role of large particles in the transport of elements and organic compounds through the oceanic water column. Prog. Oceanogr 16: 147-194

Fowler, S. W., Buat-Ménard, P., Yokoyama, Y., Ballestra, S., Holm, E., Nguyen, H. V. (1987). Rapid removal of Chernobyl fallout from Mediterranean surface waters by biological activity. Nature, Lond. 329: 56-58

Franqueville, C. (1971). Macroplancton profond (Invertébrés) de la Méditerranée Nord-occidentale. Tethys 3: 11-56

Gorsky, G., Fisher, N. S., Fowler, S. W. (1984). Biogenic debris from the pelagic tunicate, Oikopleura dioica, and its role in the vertical transport of a transuranium element. Estuar coast. Shelf Sci. 18: 13-23

Harbison, G. R., Campenot, R. B. (1979). Effects of temperature on the swimming of salps (Tunicata, Thaliacea): implications for vertical migration. Limnol. Oceanogr. 24: 1081-1091

Harbison, G. R., McAlister, V. L. (1979). The filter-feeding rates and particle retention efficiencies of three species of Cyclosalpa (Tunicata, Thaliacea). Limnol. Oceanogr 24: 875-892

Harding, G. C. H. (1973). Decomposition of marine copepods. Limnol. Oceanogr. 18: 670-673

Harrison, P. J., Turpin, D. H. (1982). The manipulation of physical, chemical and biological factors to select species from natural phytoplankton communities. In: Grice, G. D., Reeve, M. R. (eds.) Marine mesocosms. Biological and chemical research in experimental ecosystems. SpringerVerlag, New York, p. 275-289

Hofmann, E. E., Klinck, J. M., Paffenhöfer, G.-A. (1981) Concentrations and vertical fluxes of zooplankton fecal pellets on a continental shelf. Mar. Biol. 61: 327-335

Honjo, S. Roman, M. R. (1978j. Marine copepod fecal pellets: production, preservation and sedimentation. J. mar. Res. 36: $45-47$

Ikeda, T., Bruce, B. (1986). Metabolic activity and elemental composition of krill and other zooplankton from Prydz Bay, Antarctica, during early summer (November-December). Mar, Biol, 92: 545-555

Iseki, K. (1981). Particulate organic matter transport to the deep sea by salp fecal pellets. Mar. Ecol. Prog. Ser 5: $55-60$

Jacobsen, T. R., Azam, F. (1984). Role of bacteria in copepod fecal pellet decomposition: colonization, growth rates and mineralization. Bull mar. Sci. 35: 495-502

Jacques, G., Minas, H. J., Minas, M., Nival, P. (1973). Influence des conditions hivernales sur les productions phytoet zooplanctoniques en Méditerranée Nord-occidentale. II Biomasse et production phytoplanctoniques. Mar Biol. 23: 251-265

Karl, D. M., Knauer, G. A. (1984). Detritus-microbe interactions in the marine pelagic environment: selected results from the VERTEX experiment. Bull. mar Sci. 35: 550-565

Knauer, G. A., Martin, J. H., Karl, D. M. (1984). The flux of particulate organic matter out of the euphotic zone. In: Global ocean flux study. National Academy Press, Washington, D. C., p. 137-150

Krishnaswami, S., Baskaran, M., Fowler, S. W., Heyraud, M. (1985). Comparative role of salps and other zooplankton in the cycling and transport of selected elements and natural radionuclides in Mediterranean waters. Biogeochem. 1: $353-360$
Lännergren, C. (1979). Buoyancy of natural populations of marine phytoplankton. Mar Biol. 54: 1-10

Lorenzen, C. J., Welschmeyer, N. A., Copping, A. E., Vernet, M. (1983). Sinking rates of organic particles. Limnol. Oceanogr. 28: 766-769

Madin, L. P. (1982). Production, composition and sedimentation of salp fecal pellets in oceanic waters. Mar. Biol. 67 : $39-45$

Madin, L. P., Cetta, C. M., McAlister, V. L. (1981). Elemental and biochemical composition of salps (Tunicata, Thaliacea). Mar. Biol. 63: 217-226

Matsueda, H., Handa, N., Inoue, I., Takano, H. (1986). Ecological significance of salp fecal pellets collected by sediment traps in the eastern North Pacific. Mar. Biol. 91: 421-431

Moloney, C. L., Bergh, M. O., Field, J. G., Newell, R. C. (1986). The effect of sedimentation and microbial nitrogen regeneration in a plankton community: a simulation investigation. J. Plankton Res. 8: 427-445

Nival, P. (1976). Relations phytoplancton-zooplancton; essai de modélisation. Thèse de Doctorat d'Etat ès Sciences Naturelles, Université Paris VI, France

O'Brien, J. J., Wroblewski, J. S. (1973). A simulation of the mesoscale distribution of the lower marine trophic levels off West-Florida. Investigación pesq. 37: 193-244

Paffenhöfer, G.-A., Knowles, S. C. (1979). Ecological implications of fecal pellet size, production and consumption by copepods. J. mar. Res. 37: 35-49

Paffenhöfer, G.-A., Strickland, J. D. H. (1970). A note on the feeding of Calanus helgolandicus on detritus. Mar. Biol. 5: $97-99$

Pagano, M. (1980). Biologie d'un copépode des eaux saumâtres temporaires de la région méditerranéenne, Eurytemora velox (Lilljeborg, 1853): Bilan énergétique et cycle vital. Thèse 3ème cycle, Océanologie biologique, Université Aix-Marseille II, Marseille, France

Peduzzi, P., Herndl, G. J. (1986). Role of bacteria in decomposition of faecal nellets egested by the epiphyie-grazing gastropod Gibbula umbilicaris. Mar. Biol. 92: 417-424

Pomeroy, L. R., Deibel, D. (1980). Aggregation of organic matter by pelagic tunicates. Limnol. Oceanogr 25: 643-652

Silver, M. W., Alldredge, A. L. (1981). Bathypelagic marine snow: deep sea algal and detrital community. J. mar. Res. 39: $501-530$

Small, L. F., Fowler, S. W. (1973). Turnover and vertical transport of zinc by the euphausiid Meganyctiphanes norvegica in the Ligurian Sea. Mar. Biol. 18: 284-290

Small, L. F., Fowler, S. W., Moore, S. A., La Rosa, J. (1983). Dissolved and fecal pellet carbon and nitrogen release by zooplankton in tropical waters. Deep Sea Res. 30: 1199-1220

Small, L. F., Fowler, S. W., Ünlü, M. Y (1979). Sinking rates of natural copepod fecal pellets. Mar. Biol. 51: 233-241

Smayda, T. J., Boleyn, B. J. (1965). Experimental observations on the flotation of marine diatoms. I. Thalassiosira cf. nana, Thalassiosira rotula, and Nitzschia seriata. Limnol. Oceanogr. 10: 499-509

Smayda, T. J., Boleyn, B. J. (1966a). Experimental observations on the flotation of marine diatoms. II. Skeletonema costatum and Rhizosolenia setigera. Limnol. Oceanogr. 11: $18-34$

Smayda, T. J., Boleyn, B. J. (1966b). Experimental observations on the flotation of marine diatoms. III. Bacteriastrum hialinum and Chaetoceros lauderi. Limnol. Oceanogr. 11: $35-43$

Smayda, I. J., Bienfang, P. K. (1983). Suspension properties of various phyletic groups of phytoplankton and tintinnids in an oligotrophic, subtropical system. Mar. Ecol. 4: 289-300 
Smith, W O., Heburn, G. W., Barber, R. T., O'Brien, J. J. (1983). Regulation of phytoplankton communities by physical processes in up-welling ecosystems. J. mar. Res. 41: $539-556$

Steele, J. H., Henderson, E. W. (1976). Simulation of vertical structure in a planktonic ecosystem. Scott. Fish. Res. Rep. 5: $1-27$

Titman, D., Kilham, P. (1976). Sinking in freshwater phytoplankton: some ecological implications of cell nutrient status and physical mixing processes. Limnol. Oceanogr. $21 \quad 409-417$
Turner, J. T (1979). Microbial attachment to copepod fecal pellets and its possible ecological significance. Trans. Am. microsc. Soc. 98: 131-135

Vinogradov, M. Ye., Krapivin, V F., Menshutkin, V. V., Fleyshman, B. S., Shushkina, E. A. (1973). Mathematical model of the functions of the pelagial ecosystem in tropical regions. Oceanology 13: 704-717

Wiebe, P. H., Madin, L. P., Haury, L. R., Harbison, G. R., Philbin, L. M. (1979). Diel vertical migration by Salpa aspera and its potential for large-scale particulate organic matter transport to the deep-sea. Mar. Biol. 53: 249-255

This article was presented by Professor N. D. Holland; it was accepted for printing on January 29, 1988 